\title{
Physiological and Biochemical Responses to Heat Stress on Barley Seedlings and Their Impact on Growth and Yield
}

\author{
Amal M.E. Abdel-Hamid \\ Department of Biological and Geological Sciences, Faculty of \\ Education, Ain Shams University, Cairo, Egypt.
}

\begin{abstract}
THE PRESENT study was carried out to investigate the effect of two temperature degrees $\left(30 \& 40^{\circ} \mathrm{C}\right)$ on physiological and biochemical aspects of barley seedlings and their impact on growth and yield. Plant height, number of tillers, fresh weight, dry weight, flag leaf area were generally reduced following exposure to heat stress ranging between 2 and 8 hours., while relative water content was increased indicating attempts by plant to resist temperature elevation. The contents of chlorophyll $\mathrm{a}$ and chlorophyll $\mathrm{b}$ decreased significantly in leaves exposed to all treatments of heat stress while carotenoids decreased as the stress duration was prolonged. Correlation was evident between growth, some yield parameters (peduncle length, biological yield, spike length, number of spike per plant, kernels weight) and yield index. Changes in SDS protein profiles indicated the occurrence of a number of biochemical responses; some of them were positively associated with heat stress, while the others were negatively associated with heat stress.
\end{abstract}

Keywords: Barley, Heat stress, Yield, Photosynthetic Pigments, Protein Electrophoresis

Elevation in temperature due to climate change is expected to result in a reduction in cereals production particularly in developing countries (Lobell et al., 2008). Numerous reports have been published on the impact of heat stress. In wheat, both grain weight and grain number appeared to be sensitive to heat stress, as the number of grains per ear at maturity declined with increasing temperature (Ferris et al., 1998). Elevated temperature lengthened the duration of grain filling with reduction in kernel growth leading to losses in kernel density and weight by up to $7 \%$ in spring wheat (Guilioni et al., 2003). Similar reductions occurred in starch, and grain quality in other cereals under heat stress (Maestri et al., 2002), Spiertz et al. (2006) and Hakim et al. (2012) found that high temperature followed by drought (soil moisture deficit) affected all stages of wheat and barley cultivars from germination through to reproduction of crop when sown late resulting in drastic reduction in yield. Reinhardt et al. (2013) reported that high temperatures $\left(30^{\circ} \mathrm{C}\right)$ at flowering resulted in a significantly reduced number of kernels and kernel yield per plant. In addition, high temperature at flowering resulted in a decreased starch and increased protein content

*Corresponding author: amaleliwa72@yahoo.com 
for all genotypes. Protein content was negatively correlated with starch content and positively correlated with the $\beta$-amylase-activity. The waxy genotypes showed a higher temperature sensitivity regarding the investigated yield parameters than the non-waxy cultivar Lomerit.

Plants and other eukaryotes respond to heat transitory temperature elevation by synthesis of different classes of heat shock proteins (HSPs). In general HSPs prevent protein aggregation induced by heat shock and other stresses and assess in refolding the damaged proteins during recovery (Parsell and Lindquist, 1993). On the other hand, Timperio et al. (2008) specified that upon heat stress, the role of HSPs as molecular chaperones is without doubt, their function in non-thermal stress could be different: unfolding of proteins is not the main effect and protection from damage could occur in an alternative way apart from ensuring the maintenance of correct protein structure. The HSP-triggered thermo-tolerance is attributed to the observations that (a) their induction coincides with the organism under stress, (b) their biosynthesis is extremely fast and intensive, and (c) they are induced in a wide variety of cells and organisms (Wahid et al., 2007). In plants, a number of reviews (Vierling, 1991; Schöffl et al., 1998 and Kotak et al., 2007) have proposed five principal classes of Hsps characterized by their activities as molecular chaperones according to their approximate molecular weight: (1) HSP100, (2) HSP90, (3) HSP70, (4) HSP60 and (5) small heat-shock proteins (SHSPs).

There is thus a need to increase tolerance to high temperature in cereals through conventional breeding or genetic modification. Barley (Hordeum vulgare L.), which is used as feed, malt and human food, is the fourth most important cereal crops after wheat, rice and maize. Although barley is superior in terms of drought and salinity resistance over most other cereal crops, its growth and production are also greatly affected by these two stresses. The objectives of this study were to study the effects of heat stress on growth and yield of barley and to identify leaf proteins differentially regulated in response to stress using SDSPAGE .The changes in protein abundance are discussed in the context of the physiological and morphological trait plasticity that occurs due to the abiotic stresses.

\section{Material and Methods}

\section{Plant material and exposure to stress}

Grains of one cultivar of Hordeum vulgare cv. Giza 123 were kindly obtained from Barley Research Department, Field Crops Research Institute, Agriculture Research Center (ARC), Giza, Egypt. Grains of this cultivar were planted in plastic pots $(20.9 \mathrm{~cm}$ top diameter, $15.5 \mathrm{~cm}$ base diameter and $16.5 \mathrm{~cm}$ depth). Five grains were sown in each pot in green house at $15-20^{\circ} \mathrm{C}$ for two weeks, after that the plants were divided into three sets. The first one is the control; the second set was exposed to $30^{\circ} \mathrm{C}$ for 2,4 and $6 \mathrm{hr}$. The third one was exposed to $40^{\circ} \mathrm{C}$ for 2, 4 and $6 \mathrm{hr}$ in oven. Then the plants were transferred to the green house to

Egypt. J. Bot., 56, No. 1 (2016) 
complete their growth at a day/night rhythm of $14 / 10 \mathrm{~h}$ and $20 / 15^{\circ} \mathrm{C}$ until harvesting.

\section{Determination of growth and yield criteria}

After 40 days of planting, six vegetative criteria were recorded (plant height, flag leaf area, number of tillers, fresh weight, dry weight and relative water content) and leaf samples were detached for the estimation of pigments and protein extraction for the SDS-PAGE analysis. The recorded criteria were the following: plant height, estimated as the length of the main stem in $\mathrm{cm}$ from soil surface to the base of its spike, flag leaf area; calculated using the formula of Lal and Subba Rao (1951) as follows: leaf area $=0.76$ leaf length $\times$ leaf broadest width, number of tillers, fresh weight, dry weight, leaf relative water content; measured using the method of Yamasaki and Dillenburg (1999), peduncle length; measured as the length in $\mathrm{cm}$ of the top internode of the main stem at maturity, spike length; measured as the average length of five spikes, number of spikes per plant; estimated as the average number of productive tillers per plant, thousandkernel weight $(\mathrm{g})$, biological yield, measured as total aerial biomass production $(\mathrm{g})$, determined at harvest by weighing all plant parts excluding the root.

\section{Quantitative estimation of photosynthetic pigments}

The photosynthetic pigments (chlorophyll a, chlorophyll $\mathrm{b}$ and carotenoids) were determined from 40 days old-leaf extract using the spectrophotometric method recommended by Metzner et al. (1965). In brief, $5 \mathrm{~g}$ fresh weight of leaves were homogenized in $85 \%$ aqueous acetone for 5 minutes. The homogenate was centrifuged and the supernatant was made up to $100 \mathrm{ml}$ with $85 \%$ acetone. The extraction was measured against a blank of pure $85 \%$ aqueous acetone at three wavelengths of 452.5, 644 and $663 \mathrm{~nm}$ using Spekol Spectrocolourimeter VEB Carl Zeiss. Taking into consideration the dilutions made of the pigment fractions, chlorophyll a, chlorophyll $\mathrm{b}$ and carotenoids were determined as $\mu \mathrm{g} / \mathrm{ml}$ using the following equations:

Chlorophyll a $(\mu \mathrm{g} / \mathrm{ml})=10.3$ E663 -0.918 E644

Chlorophyll b $(\mu \mathrm{g} / \mathrm{ml})=19.7$ E644 -3.87 E663

Carotenoids $(\mu \mathrm{g} / \mathrm{ml})=4.2$ E452.5 - $(0.264$ Chlorophyll a +0.426 Chlorophyll b)

Then the fractions were calculated as $\mathrm{mg} / 100 \mathrm{~g}$ fresh weight of leaves.

\section{Protein electrophoresis}

Protein was extracted from leaf samples of each treatment and analyzed using SDS-PAGE according to the method of Weber and Osborn (1969). Half gram of each leaf sample was extracted with $1 \mathrm{ml}$ extraction buffer. Samples were centrifuged for $15 \mathrm{~min}$. at $14.000 \mathrm{rpm}$ at $4^{\circ} \mathrm{C}$. Supernatants containing proteins were transferred to fresh tubes. Electrophoresis was carried out in $12 \%$ gel concentration and in Tris-Glycine running buffer $(\mathrm{pH}=8.3)$. Standard protein markers (Novagen) were loaded with molecular weights 97.400, 66.200, 42.700, 
31.000 and $14.400 \mathrm{kDa}$. Gels were run at 45 volts for $15 \mathrm{~min}$, then, the voltage was raised to 80 volts till the samples reached $2 \mathrm{~cm}$ from the bottom of the gel. Gels were stained by Coomassie brilliant blue-R $250(0.5 \mathrm{~g} / \mathrm{l})$ and destained by $5 \%$ $\mathrm{MeOH} /$ acetic acid mixture. Destained gels were photographed while wet and protein banding patterns were analyzed by Gel Doc 2000. Bio-RadTM diversity database V.2.1.1.

\section{Statistical analysis}

Statistical analysis of obtained data was carried out using the Least Significance Difference test (L.S.D.) at $1 \%$ and 5\% levels of probability (Snedecor and Cochran, 1973) in order to determine the significance of difference between mean values of the measured traits following exposure to the temperature treatments.

\section{Changes in some growth parameters}

\section{Results}

The changes in some growth criteria of 40 days old barley plants following exposure of 14 days old seedlings to heat stress of $30^{\circ} \mathrm{C}$ and $40^{\circ} \mathrm{C}$ for $2,4,6$ and $8 \mathrm{hrs}$ are illustrated in Fig. 1 and given in details in Table 1. The changes in fine of the measured criteria i.e. plant height $(\mathrm{cm})$, number of tillers, fresh weight $(\mathrm{g})$, dry weight $(\mathrm{g})$ and flag leaf area $\left(\mathrm{cm}^{2}\right)$ decreased indicating negative effect of temperature stress on growth of barley seedlings at both $30^{\circ} \mathrm{C}$ and $40^{\circ} \mathrm{C}$ for 2,4 , 6 and $8 \mathrm{hr}$, as illustrated in Table 1 and Fig. 1. However, leaf relative water content increased in barley seedlings exposed to all temperature treatments.

TABLE 1. Changes in some growth parameters of 40 days old barley plants following exposure of 14 days old seedlings to heat stress at $30^{\circ} \mathrm{C}$ and $40^{\circ} \mathrm{C}$ for $2,4,6$ and $8 \mathrm{hr}$.

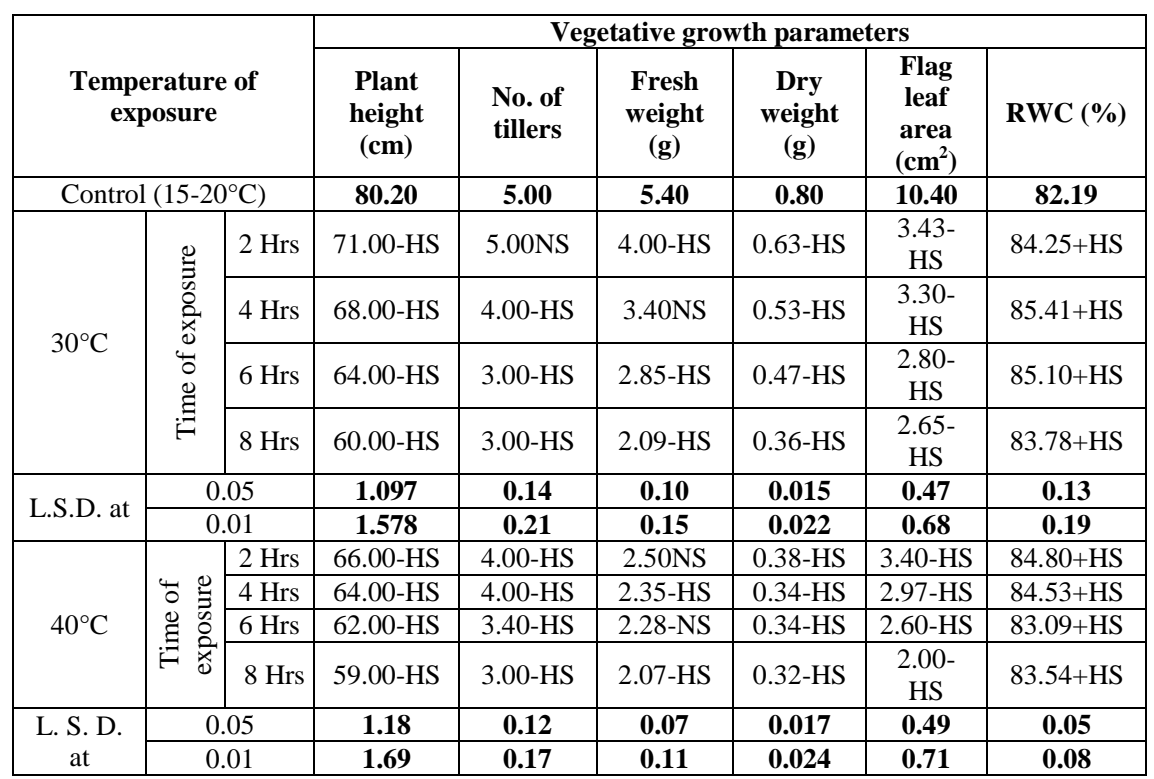

Egypt. J. Bot., 56, No. 1 (2016) 


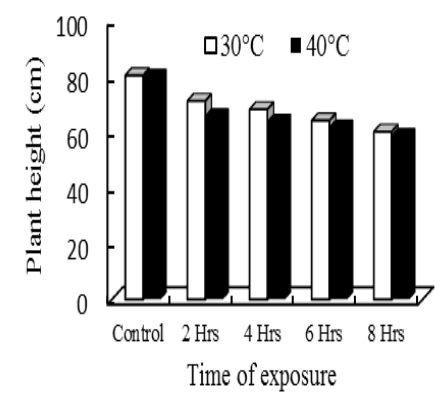

$\square 30^{\circ} \mathrm{C}-40^{\circ} \mathrm{C}$

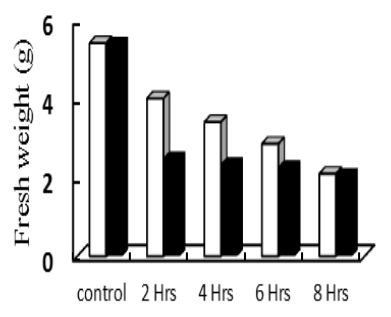

Time of exposure

$\square 30^{\circ} \mathrm{C} \quad 40^{\circ} \mathrm{C}$

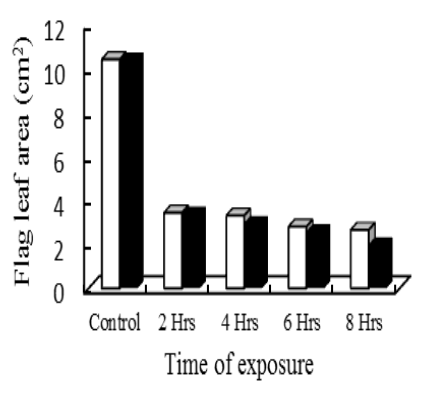

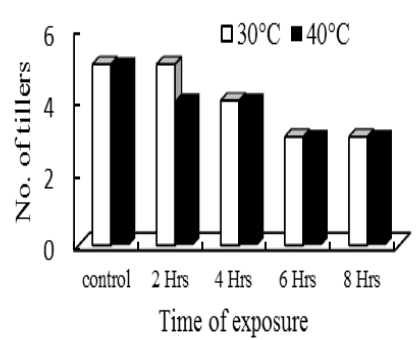

$\square 30^{\circ} \mathrm{C}-40^{\circ} \mathrm{C}$

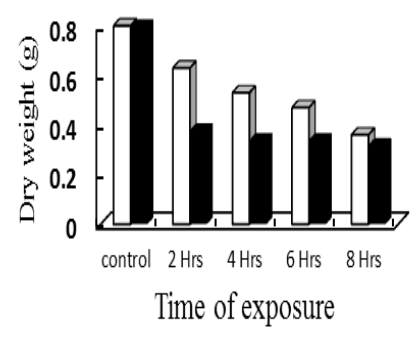

$\square 30^{\circ} \mathrm{C}-40^{\circ} \mathrm{C}$

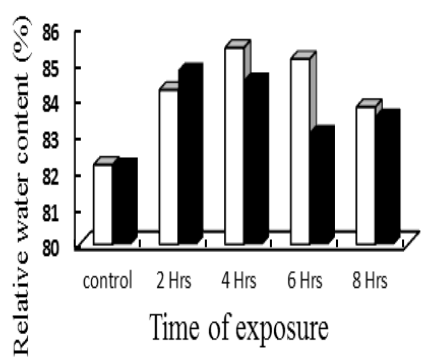

Fig. 1. Histograms illustrating changes in plant height, number of tillers, fresh weight, dry weight, flag leaf length and relative water content of 40 days old barley plants exposed to heat stress at $30^{\circ} \mathrm{C}$ and $40^{\circ} \mathrm{C}$ for $2,4,6$ and $8 \mathrm{hr}$. 


\section{Photosynthetic pigments content}

The changes in the photosynthetic pigments content in barley leaves affected by heat stress treatments are illustrated in Fig. 2 and the detailed measurements of chlorophyll a, chlorophyll b and carotenoids are given in Table 2. Chlorophyll a and chlorophyll $\mathrm{b}$ contents decreased significantly in leaves exposed to all treatments of heat stress. The reduction was more severe in plants exposed to $40^{\circ} \mathrm{C}$ compared to those exposed to $30^{\circ} \mathrm{C}$ particularly after 4,6 and $8 \mathrm{hr}$. On the other hand, the total content of carotenoids significantly increased in all treatments. The increase in the carotenoids indicates a response of the barley plants to avoid the negative effects of transient temperature stress.
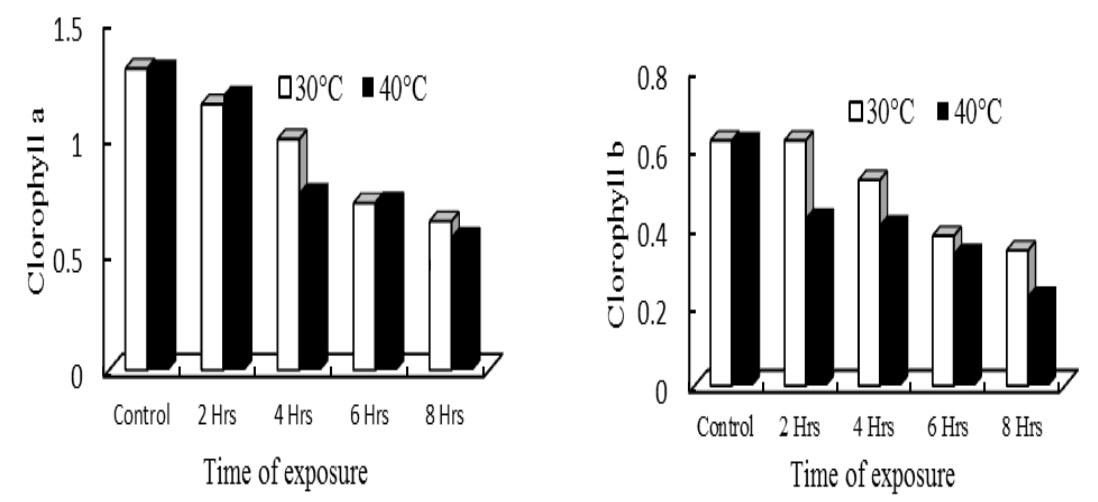

\section{$\square 30^{\circ} \mathrm{C} \backsim 40^{\circ} \mathrm{C}$}

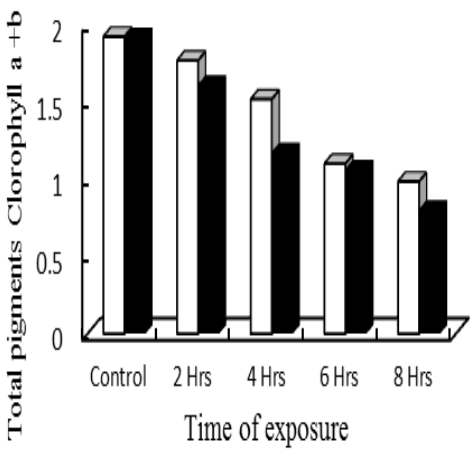

$030^{\circ} \mathrm{C}-40^{\circ} \mathrm{C}$

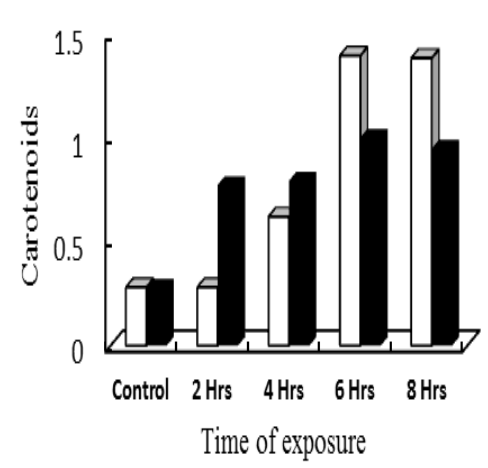

Fig. 2. Histograms illustrating changes in photosynthetic pigments; chlorophyll a, chlorophyll b, chlorophyll a+ chlorophyll b and carotenoids in 40 days old barley plants exposed to heat stress at $30^{\circ} \mathrm{C}$ and $40^{\circ} \mathrm{C}$ for $2,4,6$ and $8 \mathrm{hr}$.

Egypt. J. Bot., 56, No. 1 (2016) 
PHYSIOLOGICAL AND BIOCHEMICAL RESPONSES TO HEAT ...

TABLE 2. Changes in photosynthetic pigments content of 40 days old barley plants after exposure of 14 days old seedlings to heat stress at $30^{\circ} \mathrm{C}$ and $40^{\circ} \mathrm{C}$ for $2,4,6$ and $8 \mathrm{hr}$.

\begin{tabular}{|c|c|c|c|c|c|c|}
\hline \multirow{2}{*}{\multicolumn{3}{|c|}{$\begin{array}{l}\text { Temperature of } \\
\text { exposure }\end{array}$}} & \multicolumn{4}{|c|}{ Photosynthetic pigments } \\
\hline & & & $\begin{array}{c}\text { Chlorophyll } \\
\mathbf{a}\end{array}$ & $\begin{array}{c}\text { Chlorophyll } \\
\text { b }\end{array}$ & $\begin{array}{c}\text { Total pigments } \\
\text { Chlorophyll } \\
\mathbf{a}+\mathbf{b} \\
\end{array}$ & Carotenoids \\
\hline \multicolumn{3}{|c|}{ Control $\left(15-20^{\circ} \mathrm{C}\right)$} & 1.297 & 0.620 & 1.917 & 0.280 \\
\hline \multirow{4}{*}{$30^{\circ} \mathrm{C}$} & \multirow{4}{*}{ 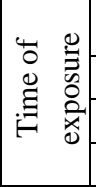 } & $2 \mathrm{hrs}$ & 1.143-HS & $0.620 \mathrm{NS}$ & 1.763-HS & $0.280-\mathrm{NS}$ \\
\hline & & $4 \mathrm{hrs}$ & 0.993-HS & $0.520-\mathrm{HS}$ & 1.513-HS & $0.620+\mathrm{HS}$ \\
\hline & & $6 \mathrm{hrs}$ & $0.718-\mathrm{HS}$ & $0.379-\mathrm{HS}$ & 1.097-HS & $1.395+\mathrm{HS}$ \\
\hline & & $8 \mathrm{hrs}$ & $0.640-\mathrm{HS}$ & 0.342-HS & 0.982-HS & $1.383+\mathrm{HS}$ \\
\hline \multirow{2}{*}{ L. S. D. at } & \multicolumn{2}{|c|}{0.05} & 0.04 & 0.02 & 0.06 & 0.08 \\
\hline & \multicolumn{2}{|c|}{0.01} & 0.06 & 0.03 & 0.08 & 0.12 \\
\hline \multirow{4}{*}{$40^{\circ} \mathrm{C}$} & \multirow{4}{*}{ 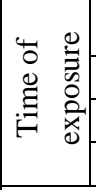 } & $2 \mathrm{hrs}$ & 1.184-HS & 0.426-HS & 1.610-HS & $0.774+\mathrm{HS}$ \\
\hline & & $4 \mathrm{hrs}$ & 0.766-HS & 0.409-HS & 1.175-HS & $0.794+\mathrm{HS}$ \\
\hline & & $6 \mathrm{hrs}$ & 0.729-HS & $0.337-\mathrm{HS}$ & 1.066-HS & $1.002+\mathrm{HS}$ \\
\hline & & $8 \mathrm{hrs}$ & 0.576-HS & 0.229-HS & 0.805-HS & $0.948+\mathrm{HS}$ \\
\hline \multirow{2}{*}{ L. S. D. at } & \multicolumn{2}{|c|}{0.05} & 0.04 & 0.02 & 0.06 & 0.04 \\
\hline & \multicolumn{2}{|c|}{0.01} & 0.06 & 0.03 & 0.09 & 0.09 \\
\hline
\end{tabular}

\section{Changes in yield-related traits}

The changes in the six measured yield related traits are shown in Fig. 3 and detailed in Table 3. All measured traits showed reductions after exposure to heat stress. The results of spike length showed significant reductions in all heat stressed plants. At maturity, all treatments displayed significant differences between control and heat treatments in number of spikes per plant. The highest mean of 1000 kernels weight under heat condition was scored for treatment with $30^{\circ} \mathrm{C}$ for $2 \mathrm{hr}$. (36.00 g), while the lowest was scored for treatment with $40^{\circ} \mathrm{C}$ for $8 \mathrm{hr} .(11.43 \mathrm{~g})$.

For biological yield, the significant reduction between control and heat stress was scored in all treatments. (Table 3 and Fig. 3). The highest mean under heat stress was scored for treatment with $30^{\circ} \mathrm{C}$ for $2 \mathrm{hr}$. $(3.65 \mathrm{~g})$, while the lowest was scored for treatment with $40^{\circ} \mathrm{C}$ for $8 \mathrm{hr}$. $(1.03 \mathrm{~g})$. 

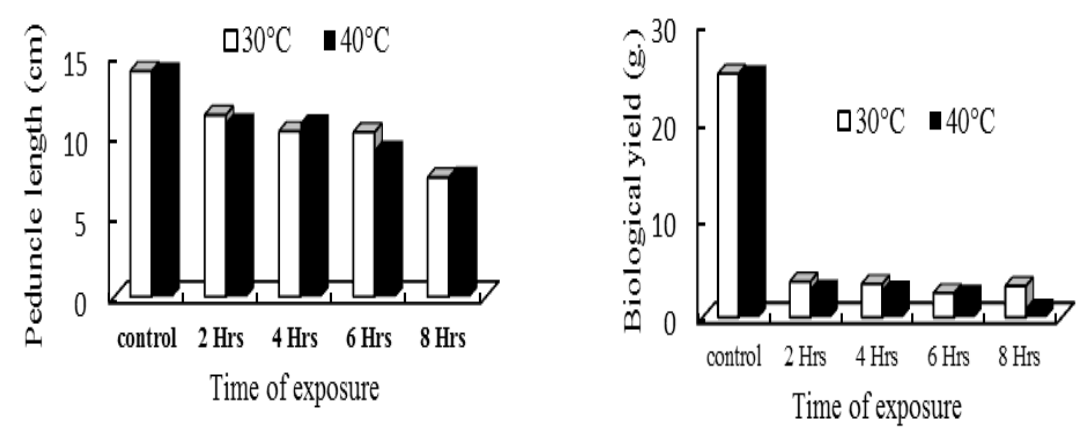

$\square 30^{\circ} \mathrm{C} 40^{\circ} \mathrm{C}$
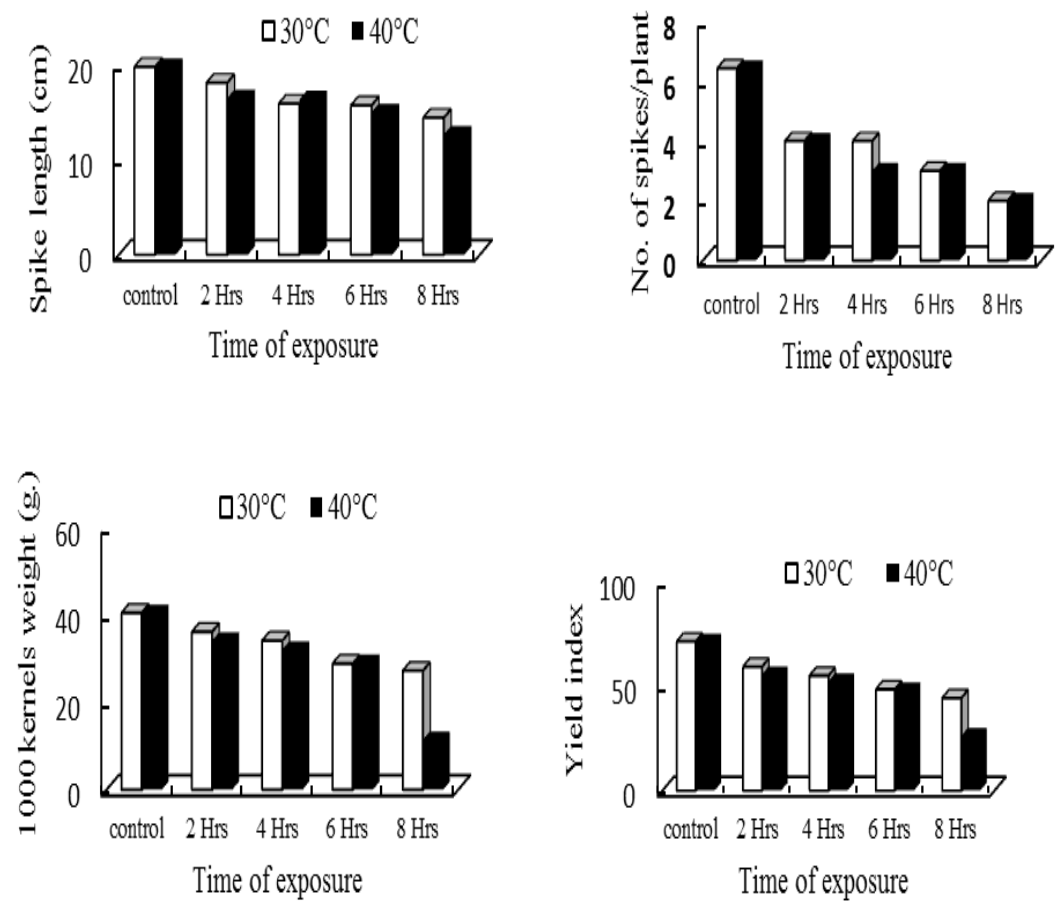

Fig. 3. Changes in some yield parameters of barley plants grown from seedlings exposed to heat stress at $30^{\circ} \mathrm{C}$ and $40^{\circ} \mathrm{C}$ for $2,4,6$ and $8 \mathrm{hr}$; peduncle length, biological yield, spike length , number of spikes per plant, 1000 kernel weight and yield index

Egypt. J. Bot., 56, No. 1 (2016) 
TABLE 3. Changes in some yield related criteria of barley plants following exposure of 14 days old seedlings to heat stress at $30^{\circ} \mathrm{C}$ and $40^{\circ} \mathrm{C}$ for $2,4,6$ and 8 hr.

\begin{tabular}{|c|c|c|c|c|c|c|c|c|}
\hline \multirow{2}{*}{\multicolumn{3}{|c|}{$\begin{array}{c}\text { Temperature of } \\
\text { exposure }\end{array}$}} & \multicolumn{5}{|c|}{ Yield related criteria } & \multirow{2}{*}{$\begin{array}{l}\text { Yield } \\
\text { index }\end{array}$} \\
\hline & & & $\begin{array}{c}\begin{array}{c}\text { Peduncle } \\
\text { length } \\
(\mathrm{cm})\end{array} \\
\end{array}$ & \begin{tabular}{|c|}
$\begin{array}{c}\text { Biologic } \\
\text { al yield } \\
\text { (g.) }\end{array}$ \\
\end{tabular} & $\begin{array}{l}\text { Spike } \\
\text { length } \\
(\mathrm{cm})\end{array}$ & $\begin{array}{c}\text { No. of } \\
\text { spikes/pl } \\
\text { ant }\end{array}$ & $\begin{array}{c}1000 \\
\text { kernels } \\
\text { weight }(\mathrm{g} .)\end{array}$ & \\
\hline \multicolumn{3}{|c|}{ Control $\left(15-20^{\circ} \mathrm{C}\right)$} & 14.00 & 24.85 & 19.66 & 6.43 & 40.33 & 71.20 \\
\hline \multirow{4}{*}{$30^{\circ} \mathrm{C}$} & \multirow{4}{*}{ 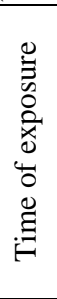 } & $\begin{array}{c}2 \\
\text { Hrs }\end{array}$ & 11.27-HS & 3.65-HS & 18.00-HS & 4.00-HS & 36.00-HS & $\begin{array}{c}59.20- \\
\text { HS }\end{array}$ \\
\hline & & $\begin{array}{c}4 \\
\text { Hrs }\end{array}$ & 10.27-HS & 3.40-HS & 15.80-HS & 4.00-HS & 34.00-HS & $\begin{array}{c}54.87- \\
\text { HS }\end{array}$ \\
\hline & & $\begin{array}{c}6 \\
\text { Hrs }\end{array}$ & 10.20-HS & 2.47-HS & 15.63-HS & 3.00-HS & 28.75-HS & $\begin{array}{c}48.36- \\
\text { HS }\end{array}$ \\
\hline & & $\begin{array}{c}8 \\
\mathrm{Hrs}\end{array}$ & 7.40--HS & 3.20-HS & 14.33-HS & 2.00-HS & 27.14-HS & $\begin{array}{c}44.17- \\
\text { HS }\end{array}$ \\
\hline \multirow{2}{*}{$\begin{array}{l}\text { L. S. D. } \\
\text { at }\end{array}$} & \multicolumn{2}{|c|}{0.05} & 0.34 & 1.39 & 0.30 & 0.24 & 0.77 & 1.50 \\
\hline & \multicolumn{2}{|c|}{0.01} & 0.49 & 1.99 & 0.44 & 0.34 & 1.11 & 2.16 \\
\hline \multirow{4}{*}{$40^{\circ} \mathrm{C}$} & \multirow{4}{*}{ 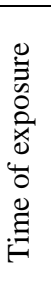 } & $\begin{array}{l}2 \\
\mathrm{Hrs} \\
\end{array}$ & 10.85-HS & 3.00-HS & 16.40-HS & 4.00-HS & 34.00-HS & $\begin{array}{c}55.55- \\
\text { HS } \\
\end{array}$ \\
\hline & & $\begin{array}{l}4 \\
\mathrm{Hrs}\end{array}$ & 10.80-HS & 2.90-HS & 16.27-HS & 3.00-HS & 32.00-HS & $\begin{array}{c}52.32- \\
\text { HS }\end{array}$ \\
\hline & & $\begin{array}{l}6 \\
\mathrm{Hrs} \\
\end{array}$ & 9.15-HS & 2.50-HS & 14.93-HS & 3.00-HS & 29.00-HS & $\begin{array}{c}47.83- \\
\text { HS } \\
\end{array}$ \\
\hline & & $\begin{array}{l}8 \\
\mathrm{Hrs}\end{array}$ & 7.53-HS & 1.03-HS & 12.58-HS & 2.00-HS & 11.43-HS & $\begin{array}{c}26.24- \\
\text { HS }\end{array}$ \\
\hline \multirow{2}{*}{$\begin{array}{l}\text { L. S. D. } \\
\text { at }\end{array}$} & \multicolumn{2}{|c|}{0.05} & 0.34 & 1.44 & 0.37 & 0.24 & 1.55 & 2.32 \\
\hline & \multicolumn{2}{|c|}{0.01} & 0.49 & 2.07 & 0.53 & 0.35 & 2.23 & 3.33 \\
\hline
\end{tabular}

Changes in protein banding patterns

The protein banding pattern for the protein extracted from barley seedlings after treatment with different durations of heat stress, showed clear differences in the number of bands and their molecular weight as indicated by the appearance of new bands or the disappearance of others (Table 4 and Fig. 4).

The electropherogram of the control showed the presence of 18 protein bands, their molecular weight ranged between 13.244 and $105.243 \mathrm{kDa}$. On the other hand, the results of treated plants with $30^{\circ} \mathrm{C}$ for $2 \mathrm{hr}$ showed the presence of 19 protein bands of molecular weights ranged between 13.244 and $105.243 \mathrm{kDa}$ and the appearance of one band with molecular weight of $33.34 \mathrm{kDa}$ and intensity of $131.44 \%$. On the other side, the treatment with $40^{\circ} \mathrm{C}$ for $2 \mathrm{hr}$ indicated the appearance of 13 bands with molecular weights ranged between 13.24 and 89.79 $\mathrm{kDa}$ and the disappearance of five bands with molecular weights 105.24, 102.92, $83.84,47.98$ and $18.39 \mathrm{kDa}$, respectively. 
TABLE 4. Molecular weights and peak optical density of proteins extracted from the seedlings produced from the grains of barley after treatment with different durations of heat stress.

\begin{tabular}{|c|c|c|c|c|c|c|c|c|c|}
\hline \multirow{2}{*}{$\begin{array}{c}\text { Mwt } \\
\text { (kDa) }\end{array}$} & \multirow[b]{2}{*}{ Control } & \multicolumn{4}{|c|}{$30^{\circ} \mathrm{C}$} & \multicolumn{4}{|c|}{$40^{\circ} \mathrm{C}$} \\
\hline & & $\begin{array}{c}2 \\
\text { hours }\end{array}$ & $\begin{array}{c}4 \\
\text { hours }\end{array}$ & $\begin{array}{c}6 \\
\text { hours }\end{array}$ & $\begin{array}{c}8 \\
\text { hours }\end{array}$ & $\begin{array}{c}2 \\
\text { hours }\end{array}$ & $\begin{array}{c}4 \\
\text { hours }\end{array}$ & $\begin{array}{c}6 \\
\text { hours }\end{array}$ & $\begin{array}{c}8 \\
\text { hours }\end{array}$ \\
\hline 105.243 & 149.28 & 170.54 & 156.13 & 147.53 & - & - & - & - & - \\
\hline 102.922 & 155.67 & 183.97 & 167.35 & 156.94 & 135.28 & - & - & - & - \\
\hline 89.79 & 149.28 & 170.54 & 156.13 & 147.53 & - & 60.25 & - & 45.28 & 18.26 \\
\hline 83.837 & 155.67 & 183.97 & 167.35 & 156.94 & 135.28 & - & - & - & - \\
\hline 80.318 & 184.36 & 192.9 & 186.18 & 185.08 & 180.74 & 172.57 & 167.68 & 170.63 & 177.31 \\
\hline 76.202 & 202.01 & 210.63 & 203.11 & 203.39 & 201.86 & 192.85 & 192.06 & 196.03 & 204.18 \\
\hline 71.578 & 183.86 & 178.61 & 178.75 & 175.19 & 172.44 & 164.15 & 156.9 & 156.92 & 166.01 \\
\hline 65.752 & 167.22 & 179.31 & 162.67 & 158.65 & 146.92 & 137.94 & 129.9 & 125.15 & 137.83 \\
\hline 60.403 & 192.79 & 205.03 & 202.19 & 198.81 & 191.76 & 174.69 & 169.71 & 180.28 & 184.03 \\
\hline 56.679 & 203.94 & 226.9 & 208.47 & 209.94 & 208.53 & 203.46 & 198.67 & 198.51 & 212.58 \\
\hline 50.503 & - & - & - & - & - & - & 87.10 & - & 99.93 \\
\hline 47.983 & 128.6 & 144.64 & - & 143.46 & 132.47 & - & 73.15 & - & 80.44 \\
\hline 43.996 & 132.6 & 145.85 & 147.82 & 144.81 & 138.5 & 128.49 & 116.53 & 132.43 & 135.86 \\
\hline 36.842 & 232.13 & 250.96 & 234 & 235.89 & 236.26 & 233.88 & 228.43 & 230.25 & 236.83 \\
\hline 33.338 & - & 131.44 & - & - & - & - & - & - & - \\
\hline 26.772 & 230.96 & 217.42 & 233.6 & 237.46 & 240.28 & 240.82 & 239.69 & 239.26 & 242.35 \\
\hline 22.000 & 214.32 & 245.82 & 211.1 & 209.07 & 205.29 & 208.42 & 199.67 & 204.88 & 209.54 \\
\hline 19.766 & - & - & 71.63 & 55.61 & 49.39 & - & - & - & - \\
\hline 18.394 & 110.43 & 99.1 & 75.17 & 55.90 & - & - & - & - & - \\
\hline 15.916 & 214.88 & 208.17 & 213.54 & 207.97 & 202.56 & 204.79 & 200.15 & 198.72 & 201.9 \\
\hline 13.244 & 252.07 & 237.26 & 253.36 & 253.53 & 252.97 & 253.5 & 253.24 & 252.99 & 253.15 \\
\hline $\begin{array}{l}\text { No. of } \\
\text { bands }\end{array}$ & 18 & 19 & 18 & 19 & 16 & 13 & 14 & 13 & 15 \\
\hline
\end{tabular}

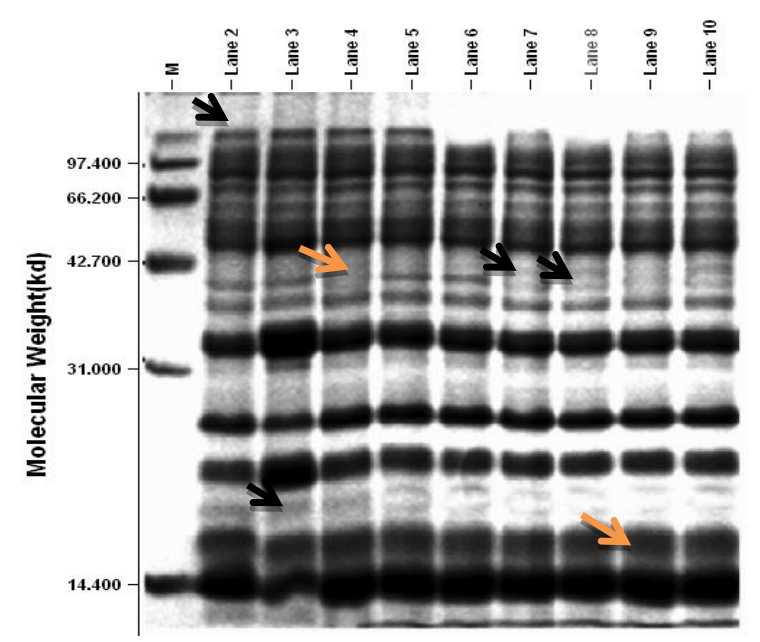

Fig. 4. Electrophoretic banding profiles of protein extracted from barley seedlings grown from grains of barley exposed to heat stress for $2,4,6$, and $8 \mathrm{hr}$.

Egypt. J. Bot., 56, No. 1 (2016) 
The total number of bands in plants treated with $30^{\circ} \mathrm{C}$ for $4 \mathrm{hr}$ was 18 . The treatment enhanced the production of one new band with molecular weight of $19.77 \mathrm{kDa}$ and an intensity of $71.63 \%$. Also one band was disappeared with molecular weight $47.98 \mathrm{kDa}$. Treatment for $4 \mathrm{hr}$ at $40^{\circ} \mathrm{C}$ showed the appearance of 14 bands; their molecular weights ranged between 13.24 and $80.32 \mathrm{kDa}$. Five bands with molecular weights of 105.24, 102.92, 89.79, 83.84 and $18.39 \mathrm{kDa}$ were not observed following heat treatments whereas one new band with molecular weight $50.50 \mathrm{kDa}$ and $87.10 \%$ intensity .

The obtained results after $6 \mathrm{hr}$. at $30^{\circ} \mathrm{C}$ revealed the presence of 19 protein bands with molecular weights ranging between 105.24 and $13.24 \mathrm{kDa}$; the appearance of one new band with molecular weight $19.77 \mathrm{kDa}$ was evident compared with the control. At the same time, treatment at $40^{\circ} \mathrm{C}$ produced 13 bands and five bands were absent; their molecular weights were 105.24, 102.92, 83.84, 47.98 and $18.39 \mathrm{kDa}$, respectively.

The treatments for $8 \mathrm{hr}$. at $30^{\circ} \mathrm{C}$ showed 16 bands; their molecular weight ranged from $102.92 \mathrm{kDa}$ to $13.20 \mathrm{kDa}$. This treatment stimulated the production of a new band with molecular weight $19.77 \mathrm{kDa}$ and disappearance of three bands with molecular weights $105.24,89.79$ and $18.39 \mathrm{kDa}$, respectively. In the other treatment, at $40^{\circ} \mathrm{C}$ for $8 \mathrm{hrs}$. produced 15 bands including one new band with molecular weight $50.50 \mathrm{kDa}$ and intensity $99.93 \%$. On the other hand, four bands with molecular weights 105.24, 102.92, 83.84 and 18.39 kDa were absent. The band with molecular weight $50.50 \mathrm{kDa}$ was appeared only in treatment with $40^{\circ} \mathrm{C}$ for 4 and $8 \mathrm{hr}$. Also the band with molecular weight $47.98 \mathrm{kDa}$ was disappeared after $4 \mathrm{hr}$. treatment at $30^{\circ} \mathrm{C}$ but appeared at $4 \mathrm{~h}$ at $40^{\circ} \mathrm{C}$. Finally, the small band with molecular weight of $19.77 \mathrm{kDa}$ appeared only following treatment with 4,6 and $8 \mathrm{hr}$. at $30^{\circ} \mathrm{C}$.

\section{Discussion}

The measurements of growth related traits in 40 days old barley plants confirmed earlier reports by Chu et al. (1974) that plant height was inhibited and leaf chlorophyll decreased by high temperature in barley; these effects were accentuated by accompanying water-stress in the leaves. These effects were confirmed for a range of temperatures extending to a maximum of $41^{\circ} \mathrm{C}$. The major impact of high temperatures on shoot growth is a severe reduction in the length of the first internode, resulting in the premature death of plants (Hall, 1992). Our findings related to dry matter reduction under heat stress are in agreement with observations by other reports on wheat Hossain and Teixeira da Silva (2012) and Hakim et al. (2012). Our results are in agreement with the view that heat stress is one of the most important causes of reduced yield and dry matter production in wheat Al-Khatib and Pallsen (1984). 
The Grains Research and Development Corporation GRDC stated flag leaf is most important organ of wheat regarding its contribution to grain yield (43\%) (GRDC, 2003). Therefore, flag leaf area is a very important determinant of grain yield in wheat. Our data on flag leaf area in barley also supported the earlier findings by Al-Khatib and Pallsen (1984) who reported that high temperature adversely affected source and sink activities and accelerated the decline in viable leaf blade area and photosynthetic activity per unit leaf area, resulting in reduced dry weight of wheat.

Volkova and Koshin (1984) stated that temperature above $41^{\circ} \mathrm{C}$ decreases the potential photosynthetic rate of leaves in both heat-resistant and-susceptible wheat varieties. The reduction in the measured vegetative growth criteria may be explained by the view of Wahid et al. (2007) that transitory or constantly high temperatures cause an array of morpho-anatomical, physiological and biochemical changes in plants, which affect plant growth and development and may lead to a drastic reduction in economic yield. Heat stress affects plant growth throughout its ontogeny, though heat-threshold level varies considerably at different developmental stages. At early stages of growth, high temperature may adversely affect photosynthesis, respiration, water relations and membrane stability, and also modulate levels of hormones and primary and secondary metabolites Wahid et al. (2007).

The reduction in the amount of chlorophyll a and chlorophyll $\mathrm{b}$ recorded here is congruent with previous reports by Li et al. (2006) and Ashraf \& Harris (2013) that the components of the photosynthetic apparatus could be damaged significantly in drought sensitive genotypes of barley, while drought tolerant genotypes were relatively less affected. Li et al. (2006) concluded that evaluation of chlorophyll content and fluorescence parameters may be indicators of drought tolerance in barley.

Since the mechanism of photosynthesis involves various components, including photosynthetic pigments any reduction in these pigments by a stress may reduce the overall photosynthetic capacity plants (Ashraf and Harris, 2013). On the hand, carotenoids are considered to be the main $\mathrm{O} 2$ quenchers in chloroplasts and under stress the oxidation of the carotenoid $\beta$-carotene may lead to the accumulation of different volatile derivatives. Toth et al. (2005) attributed the reduction in photosynthetic pigments to abrupt damage of the PSII units, loss of their capacity of oxygen evolution leading to a restricted electron transport and thus reduced rate of photosynthesis. The reduced rate in photosynthesis may have contributed to the reduction in plant height, number of tiller, fresh weight and dry weight since the production of biomass is the result of photosynthesis (Rajala et al., 2011).

In the present investigation, high genetic variation was observed in SDSPAGE profiles, which indicated that improvement through simple selection for these agronomic traits is possible through protein markers indicated by protein electrophoresis. Specific protein bands are also markers that may be useful for genotypes identification and the establishment of property rights (Mittal and Egypt. J. Bot., 56, No. 1 (2016) 
Boora, 2005). Evaluation protein profiles are essential to ensure its efficient and effective use in biological studies.

The novel markers scored here are HSPs that may act as molecular chaperones (Timperio et al. 2008). Kotak et al. (2007) have proposed five principal classes of Hsps characterized by their activities as molecular chaperones according to their approximate molecular weight: (1) HSP100, (2) HSP90, (3) HSP70, (4) HSP60, and (5) small heat-shock proteins (SHSPs). Some of these have been identified in barley seedling, however the fact that most growth and yield parameters were reduced after exposure to stress indicate limited role of the novel proteins in thermotolerance of barley seedlings. This may be associated with the application of heat shocks as different stages of plant growth and development differ in their sensitivity to high temperature depending genotype (Badr et al., 1998).

So, the results of this study indicated that the occurrence of a number of biochemical and physiological responses; some of them were positively associated with heat stress, while the others were negatively associated with heat stress.

Acknowledgments: I am grateful to Prof. Dr. Abdel fattah Badr, professor of Genetics at the Department of Botany and Microbiology, Faculty of Science, Helwan University, for revising the manuscript.

\section{References}

Al-Khatib, K. and Pallsen, G.M. (1984) Mode of high temperature injury to wheat during grain development. Physiol. Plant. 61: 363-368.

Ashraf, M. and Harris, P.J. (2013) Photosynthesis under stressful environments: An overview. Photosynthetica, 51 (2): 163-190.

Badr, A., Haider, A.S., Badr, S.F. and Radwan, S.A. (1998) Genotypic variation within Egyptian wheat varieties in response to salt stress and heat shock. Proc. Int. Cong. Mol. Genetics, Cairo 21-25 Feb., 98, Vol.1, pp:11-18.

Chu, T.M., Aspinall, D. and Paleg, L.G. (1974) Stress Metabolism. VI. Temperature stress and the accumulation of proline in barley and radish. Aust. J. Plant Physiol., 1: 87-97.

Ferris R., Ellis, R.H., Wheeeler, T.R. and Hadley, P. (1998) Effect of high temperature stress at anthesis on grain yield and biomass of field grown crops of wheat. Plant Cell Environ, 34: 67-78.

GRDC; Grains Research and Development Corporation (2003) Cereal growth stages and their importance to fungicide application. GRDC project report 2002-03, pp. 1-4. 
Guilioni, L., W'ery, J. and Lecoeur, J. (2003) High temperature and water deficit may reduce seed number in field pea purely by decreasing plant growth rate. Funct. Plant Biol., 30: 1151-1164.

Hakim, M.A., Hossain, A., Teixeira da Silva, J.A., Zvolinsky, V.P. and Khan, M.M. (2012) Yield, protein and starch content of 20 wheat (Triticum aestivum L.) genotypes exposed to high temperature under late sowing conditions. J. Sci. Res., 4 (2): 477-489.

Hall, A.E. (1992) Breeding for heat tolerance. Plant Breed. Rev., 10: 129-168.

Hossain A., Teixeira da Silva J.A. (2012) Phenology, growth and yield of three wheat (Triticum aestivum L.) varieties as affected by high temperature stress. Not. Sci. Biol., 4 (3): 97-106.

Kotak, S., Larkindale, J., Lee U., von Koskull-Döring, P., Vierling, E. and Scharf, K.D. (2007) Complexity of the heat stress response in plants. Curr. Opin. Plant Biol., 10: $310-316$.

Lal, K.N. and Subba Rao, M.S. (1951) A rapid method for flag leaf area determination. Nature. 167: 72 .

Li, R.I., Guo, P., Michael, B., Stefania, G. and Salvatore, C. (2006) Evaluation of chlorophyll content and fluorescence parameters as indicators of drought tolerance in barley. Agricultural Sciences China, 5(10): 751-757.

Lobell, D.B., Burke, M.B., Tebaldi, C., Mastranddrea, M.D., Falcon, W.P. and Naylor, R.L. (2008) Supporting online materials for prioritizing climate change adaptation needs for food security in 2030. Science, 319: 607-610.

Maestri, E., Klueva, N., Perrotta, C., Gulli, M., Nguyen, H.T. and Marmiroli, N. (2002) Molecular genetics of heat tolerance and heat shock proteins in cereals. Plant Mol. Biol., 48: 667-681.

Metzner, H., Rau, H. and Senger, H. (1965) Untersuchungen zur Synchronisierbareit einzelner Pigment mangel Mutanten von Chlorella. Planta., 65: 186-194.

Mittal, M. and Boora K.S. (2005) Molecular tagging of gene conferring leaf blight resistance using microsatellites in sorghum [Sorghum bicolor (L.) Moench]. Indian J. Exp. Biol., 43: 462-6.

Parsell, D.A. and Lindquist, S. (1993) The function of heat shock proteins in stress tolerance: degradation and reactivation of damaged proteins. Annu Rev. Genet., 27: 437-496.

Rajala, A., Hakala, K., Makela, P. and Sainio, P.P. (2011) Drought effect on grain number and grain weight at spike and spikelet level in six-row spring barley. Journal of Agronomy and Crop Science, 197(2): 103-112.

Reinhardt, D., Jansen, G., Seddig, S. and Eichler-Löbermann, B. (2013) Temperature stress during flowering time affects yield and quality parameters of waxy barley. Appl agric forestry Res., 63: 79-84.

Egypt. J. Bot., 56, No. 1 (2016) 
Schöffl, F., Prändl, R. and Reindl, A. (1998) Regulation of the heat shock response. Plant Physiol., 117: 1135-1141.

Snedecor, G.W. and Cochran, W.G. (1973) "Statistical Methods". $6^{\text {th }}$ ed., Iowa State University Press, Iowa, USA. pp. 593.

Spiertz, J.H., Hamer, R.J., Xu, H., Primo-Martin, C., Don, C. and van der Putten, P.E. (2006) Heat stress in wheat (Triticum aestivum L.): Effects on grain growth and quality traits. Europ. J. Agronomy, 25: 89-95.

Timperio, A. M., Egidi, M.G. and Zolla, L. (2008) Proteomics applied on plant abiotic stresses: role of heat shock proteins (HSPs). J. Proteomics, 71: 391-411.

Toth, S.Z., Schanske, G., Kissimon J., Kovacs L., Garab G. and Strasser, R.J. (2005) Biophysical studies of photosystem II-related recovery processes after a heat pulse in barley seedlings (Hordeum vulgare L.). Journal of Plant Physiology, 162: 181-194.

Vierling, E. (1991) The role of heat shock proteins in plants. Annu. Rev. Plant Phys., 42: 579-620.

Volkova, A.M. and Koshin, V.A. (1984) The influence of high temperature on photosynthesis and chlorophyll content in spring wheat varieties differing in heat resistance. Aust. J. Plant Physiol. 87: 76-81.

Wahid, A., Gelani, S., Ashraf, M. and Foolad, M.R. (2007) Heat tolerance in plants: An overview. Environmental and Experimental Botany 61: 199-223.

Weber, K., Osborn, M. (1969) The reliability of molecular weight determinations by dodecyl sulfate-polyacrylamide gel electrophoresis, J. Biol. Chem. 25: 244(16): 44064412.

Yamasaki, S. and Dillenburg, L.R. (1999) Measurements of leaf relative water content in Araucaria Angustifolia, Revista Brasileira de Fisiologia Vegetal, 11(2): 69-75.

(Received 6/7/2015; accepted 2/9/2015) 


\section{الإستجابات الفسيولوجية والبيوكيميائية للإجهاد الحراري لبادرات نبات الثعير وتأثير ذلك على النمو والإنتاجية}

د. أمل كمح عليوة عبد الحميد

قسم العلوم البيولوجية و الجيولو عليو المبية ـ كلية التربية ـ جامعة عين شمس - القاهرة -

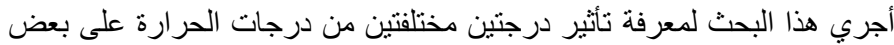

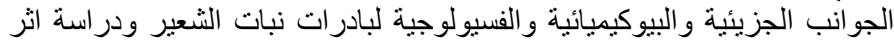

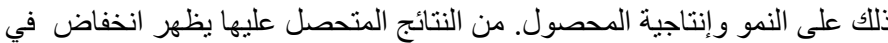

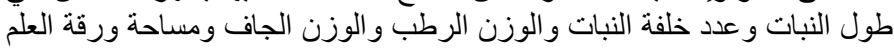

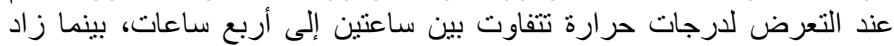

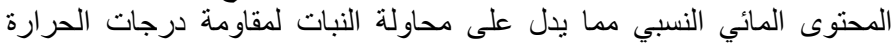

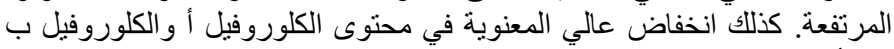

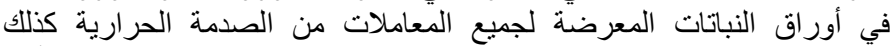

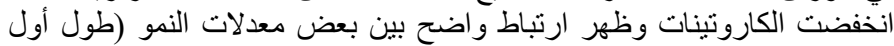

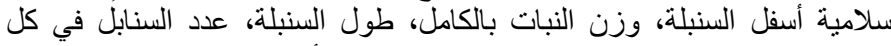

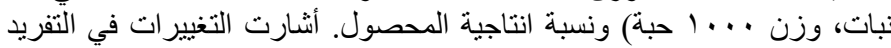

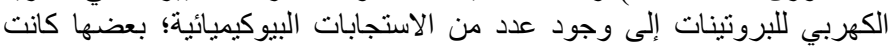

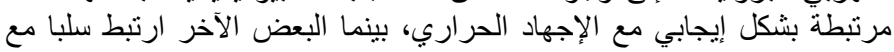
الإجهاد الحراري. 